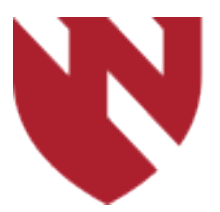

September 2020

\title{
Acute Onset Parkinson's Disease Secondary to West Nile Virus Encephalitis
}

\author{
Matthew V. Purbaugh \\ University of Nebraska Medical Center \\ Fuad-al Ali \\ University of Nebraska Medical Center \\ T. Scott Diesing \\ University of Nebraska Medical Center \\ Amy Hellman \\ University of Nebraska Medical Center
}

Tell us how you used this information in this short survey.

Follow this and additional works at: https://digitalcommons.unmc.edu/gmerj

Part of the Higher Education Commons, and the Medicine and Health Sciences Commons

\section{Recommended Citation}

Purbaugh, M. V., Ali, F., Diesing, T., , Hellman, A. Acute Onset Parkinson's Disease Secondary to West Nile Virus Encephalitis. Graduate Medical Education Research Journal. 2020 Sep 29; 2(1).

https://digitalcommons.unmc.edu/gmerj/vol2/iss1/74

This Conference Proceeding is brought to you for free and open access by DigitalCommons@UNMC. It has been accepted for inclusion in Graduate Medical Education Research Journal by an authorized editor of DigitalCommons@UNMC.For more information, please contact digitalcommons@unmc.edu. 


\section{Acute Onset Parkinson's Disease Secondary to West Nile Virus Encephalitis \\ Creative Commons License \\ (C) $(\mathbb{\theta} \Theta \Theta$}

This work is licensed under a Creative Commons Attribution-Noncommercial-No Derivative Works 4.0 License. 
SDS is associated with an increased risk of developing myelodysplastic syndrome (MDS) and leukemia. Hematopoietic stem cell transplantation (HSCT) is the only curative treatment of bone marrow dysfunction in SDS. Indications for transplant include severe cytopenias, MDS, and leukemia.

Methods: Bone Marrow Biopsy, Transplant. Consent was obtained to use this case for educational purposes.

Results: A 2 month-old male presented with pallor, diarrhea and anemia. He subsequently developed thrombocytopenia and neutropenia. A bone marrow biopsy was performed and demonstrated hypocellular bone marrow. Parents reported a history of oily stools and lab findings were suggestive of pancreatic insufficiency. The patient had an inconclusive genetic work-up but was clinically diagnosed with SDS. The patient was weekly transfusions at 4 yearsold. Due to his transfusion dependence, he was determined to be a candidate for HSCT. The patient received a novel reduced intensity conditioning followed by an allogeneic mismatched unrelated bone marrow transplant. Complications following transplant included mucositis, moderate veno-occlusive disease, and disseminated adenovirus. He is now 6 years-old, fully engrafted, off immunosuppression, and transfusion-independent.

Conclusion: Our patient is the first in Nebraska with SDS to receive a successful HSCT. Early recognition and diagnosis of the disease can decrease the incidence of MDS/ AML and transfusion-related complications. In SDS patients who progress to transplant, reduced intensity conditioning can decrease transplant-related morbidity and mortality and improve long-term quality of life.

https://doi.org/10.32873/unmc.dc.gmerj.2.1.070

\section{Acute Onset Parkinson's Disease Secondary to West Nile Virus Encephalitis Matthew Purbaugh ${ }^{1}$, Fuad-al Ali ${ }^{1}$, T. Scott Diesing ${ }^{1}$, Amy Hellman $^{1}$}

${ }^{1}$ University of Nebraska Medical Center, Department of Neurological Sciences

\section{Mentor: Amy Hellman}

Program: Neurological Sciences

Type: Case Report

Background: Acute onset Parkinsonism has a variety of causes including dopamine antagonists, strokes and viral causes including flaviviruses such as WNV, St. Louis encephalitis and Japanese encephalitis, and influenza.

Methods: History, physical exam, laboratory studies and MRI.

Results: A healthy, well-functioning 79-yearold male with PMH of MCI presented with right sided tremor, fever, encephalopathy and meningismus, with no previous history of movement disorders. Physical exam revealed bilateral upper extremity cog-wheel rigidity, narrow-based gait with decreased arm swing, 4-step turn, prominent right-sided resting tremor, facial tremor, bradykinesia with decrement on finger tapping and myoclonus. MRI showed white matter disease consistent with chronic small vessel disease. CSF showed pleocytosis with monocyte predominance, elevated protein and WNV IgM indicating an acute infection. The Parkinsonism started to show improvement and five months later he reported continued improvement in his tremor with a minor residual postural tremor, resolution of the myoclonus and improvement in his gait. He continued to have difficulty functioning at his prior level due to bradykinesia and worsening of his preexisting MCI.

Conclusion: Viral induced Parkinsonism has been previously ascribed to a variety of viruses including WNV. ${ }^{1,2,3}$ One case in 2003 described two relatively healthy patients who developed an acute encephalitis and concurrent parkinsonism that resolved with resolution of the disease. ${ }^{2}$ While a rare cause of Parkinsonism, WNV should be suspected in cases of acute onset Parkinson's disease (PD) that occurs during or after a febrile illness. Further investigation is required to determine the incidence, predisposing factors and the likelihood of developing idiopathic PD.

https://doi.org/10.32873/unmc.dc.gmerj.2.1.090

\section{References}

1 Jang H, Boltz DA, Webster RG, Smeyne RJ. (2009). Viral parkinsonism. Biochim Biophys Acta. 1792(7):714-21.

2 Robinson RL, Shahida S, Madan N, Rao S, Khardori N. (2003). Transient parkinsonism in West Nile virus encephalitis. American Journal of Medicine 15(3):252-3

3 Solomon T, Fisher AF, Beasley DWC, Mandava P, Granwehr BP, Langsjoen H, Tracassos RD, Barrett, ADT, Resh, RB. (2003). Natural and Nosocomial Infection in a patient with West Nile Encephalitis and Extrapyramidal Movement Disorders. Clinical Infectious Disease 36:e140-5.

\section{Neuroinvasive West Nile Virus: A Case Series in Nebraska Matthew Purbaugh ${ }^{1}$, Erin Smith ${ }^{1}$, T. Scott Diesing ${ }^{1}$, Sachin Kedar ${ }^{1}$}

${ }^{1}$ University of Nebraska Medical Center, Department of Neurological Sciences

\section{Mentor: Sachin Kedar}

Program: Neurological Sciences

Type: Case Report

Background: Between May and October 2018, there were 110 reported cases of neuroinvasive West Nile Virus (WNV) in Nebraska. The arbovirus can have many CNS manifestations including meningoencephalitis, poliomyelitis like syndrome, and movement disorders. We present four unusual presentations of neuroinvasive WNV seen during the summer of 2018.
Methods: We reviewed charts of four patients admitted to neurology service who had positive serology and/or polymerase chain reaction (PCR) testing for $\mathrm{WNV}$.

Results: Case 1: A 39-year-old female with diffuse large B-cell lymphoma presented with fever, encephalopathy, and flaccid paraplegia. MRI showed T2 hyperintensities involving the bilateral thalami, temporal lobes, midbrain, pons, and spinal cord which were suspicious for CNS lymphoma. WNV was confirmed by PCR as her prior treatment with RCHOP made her serum and CSF serology falsely negative. Case 2: A 49-year-old female presented with left sided ptosis and left arm weakness. WNV was confirmed by CSF lymphocytic pleocytosis and positive WNV IgM. Case 3: A 79-year old male presented with acute onset parkinsonism with positive CSF WNV IgM. Case 4: A 31 year-old male who presented with uveomeningitis syndrome with uveitis of the right eye, fever, headache, nuchal rigidity and CSF pleocytosis. An autoimmune cause was suspected until CSF showed WNV IgM. All four patients showed varying amounts of neurological recovery with supportive care. 